\title{
A procedure of repairing housing defects in development investments
}

\author{
Edyta Plebankiewicz ${ }^{1}$, Krzysztof Zima ${ }^{1}$, Jarosław Malara ${ }^{1}$, and Sebastian Biel ${ }^{1 *}$ \\ ${ }^{1}$ Institute of Management in Civil Engineering, Faculty of Civil Engineering, Tadeusz Kościuszko University of Technology, 24 \\ Warszawska Street, 31-155 Krakow, Poland
}

\begin{abstract}
The article presents the results of the analysis of defects revealed by the supervision inspector during the acceptance of works in one of the Krakow multi-apartment buildings. During the tests, it was found that the most frequently occurring defects include: cracks in walls and ceilings, scratched glass, lack of straight angles between the walls or scratched window sills. There is an average of 11.32 defects per apartment and 0.23 defects per square meter of apartments. It was revealed that very significant, significant and insignificant defects had a similar quantitative share. A procedure for the reception of apartments was proposed, which will be the basis for the development of a mathematical model supporting decision making at the time of acceptance.
\end{abstract}

\section{Introduction}

An investor of a building object, newly erected or modernized, expects from his contract partner (that is, the contractor) obtaining a building that is free of building defects; therefore, disputes regarding defects in newly built buildings are fully justified. Yet it should be noted that some claims are unjustified: stains, dirt, scratches or minor irregularities are inevitable. From contractors who often work in difficult conditions (for example, atmospheric) one cannot expect perfect [1] accuracy in the construction works they perform. Differences of opinion about defects are the cause of many conflicts.

Chrabczyński and Heine defined the defect as unfavorable and unintended property of the constructed object, making it difficult to use it as intended or its preservation or reducing its aesthetics or comfort of users which can be repaired using appropriate building techniques. The defect is not only a property, but also the lack of properties of the construction object that the contractor has promised the investor. [2] The investor has the right to obtain a building without defects - this is guaranteed in $\S 1$ art. 556 of the Civil Code [3], which describes the defect as follows:

A physical defect is the incompatibility of the item sold with the contract. In particular, the item sold is inconsistent with the contract, if:

- does not have properties that this type of item should have due to the purpose of the contract marked or resulting from the circumstances or destination;

- does not have the properties that the seller has provided for the buyer, including a sample or pattern;

- is not suitable for the purpose of which the buyer informed the seller at the conclusion of the contract, and the seller did not raise any objections to such a destination;

- has been delivered to the buyer incomplete.

Therefore, a defect can be considered as fault that deviates significantly from the agreements contained in the contract.

When assessing defects in housing facilities, they can be divided into three groups. One includes defects that an investor cannot challenge: the assessment may show that the irregularities detected do not exceed the limit values set in the contract, regulations or the construction art and can be considered as expected or commonly occurring. These types of defects are seen as unavoidable and not subject to complaints. The next group are defects which should be removed by the contractor. If the removal of the defects detected is possible and the cost is acceptable, the investor has the right to demand their removal and the contractor should do so. The last group are defects that cannot be removed. It often happens that the cost of repairing the defect revealed can be disproportionately high compared to the effect that can be obtained after repair. In such a situation, the investor has the right to refrain from demanding the defect to be removed by the contractor, in return demanding a corresponding equivalent, such as money.

There are relatively many reasons for defects in the newly constructed buildings, as each construction is different and each one varies from all the previous ones. The main reasons include the following:

- design errors - for instance, incorrect technological solutions in the underground part of the building, foundations, supporting structure, roof structure or indication of inappropriate material solutions in the construction documentation. 
- executive errors - for example, use of materials of inadequate quality or inconsistent with the design or faulty construction of building elements..

- operation of external environment factors - such as moisture of building elements, grounding and freezing of the ground, low temperature when constructing temperature-sensitive elements, vibrations and shocks.

The purpose of the article is to examine the amount, type and location of housing defects. The authors also want to analyze the process of flat acceptance, both by the supervision inspector and the owner. The results of the research will be the basis for creating a decision making tool, that can be used to make a decision by the supervision inspector about the acceptance of the flat according to the cost of the repair of the defects.

Research related to housing defects has been conducted for many years in various parts of the world. The study of factors contributing to building failures and defects in buildings has been addressed, among others, by: N. Ahzahar, N.A. Karim, S.H. Hassan and J. Eman [4]; Nurul N. and Bakri O. [5]; Ismail I., Che-Ani A. I., Razak M., Mohd Tawil N. and Johar S. [6]. The analysis of the process of detecting housing defects during acceptance in newly built buildings in New Zealand, as well as their causes, was undertaken by Rotimi F.E., Tookey J. and Rotimi J.O. [7]; F.E. Rotimi [8] in the doctoral dissertation. Ojo A.M. and Ijatuyi O.O. [9], on the basis of a housing estate located in Nigeria, discussed defects in residential constructions. Hammad D.B, Shafiq N. and Nuruddin M.F. [10] classified the criticality of detected defects by means of analytical tools, namely, by using the AHP multicriteria method. One of the most important activities in the construction industry is quality control and systematic improvement: Fernandez, González, Cabal and Balsera [11] analysed the issue on the example of housing in Spain.

Also in Poland, defects in apartments have been the subject of many analyses. Dubas S., Nowotarski P. and Milwicz R. [12] discussed the most common building defects detected during the final acceptance of flats. According to the authors, the most frequent defects included: improperly working woodwork, as well as its fittings, deviations from the plaster surface, lack of a straight angle between the walls, cracks and contamination of equipment elements. Oswald R. and Abel R. [13] analysed the recognition, prevention and methods of removing defects in buildings, while Czupajłło J. [14] presented many construction defects in his publication, along with the rules and possible ways of repairing incorrectly made works.

The process of a development venture is an important issue worth mentioning when examining housing defects, which was analyzed in K. Zima's doctoral dissertation [15], as well as the investment process itself discussed by M. Połoński [16]. It is also worth paying attention to the choice of the construction contractor, because it strongly influences the number and type of housing defects: this issue was analyzed by Plebankiewicz E. and Dziadosz A. [17]. During the study of defects, the authors also got acquainted with the real estate market in Poland using, Fig. 2 shows defects which were detected during acceptance along with the frequency of their occurrence. among others, the publication of Kozik R. and Zima K. [18] regarding the analysis of housing investments in Krakow.

\section{The results of the study on defects detected during house acceptance}

In order to learn about the problem of defects in residential buildings, the authors conducted surveys. They were based on data from apartment acceptance carried out by the inspector in 2017, in one of the Krakow buildings constructed by a developer. The building under examination is a residential building, consisting of 15 floors. The building was divided into three staircases. The investment has 172 apartments with a total area of over $8,000 \mathrm{~m} 2$.

The residential building, subjected to analysis, is based on a foundation slab, consists of one underground garage floor and above-ground part. Structural walls in basements and parts of above-ground level are made of reinforced concrete. The last four floors of the building as well as partition walls have been lined with silicate blocks and ceilings were designed in the form of monolithic reinforced concrete slabs.

The research identified the rooms in which defects are found (Fig. 1).

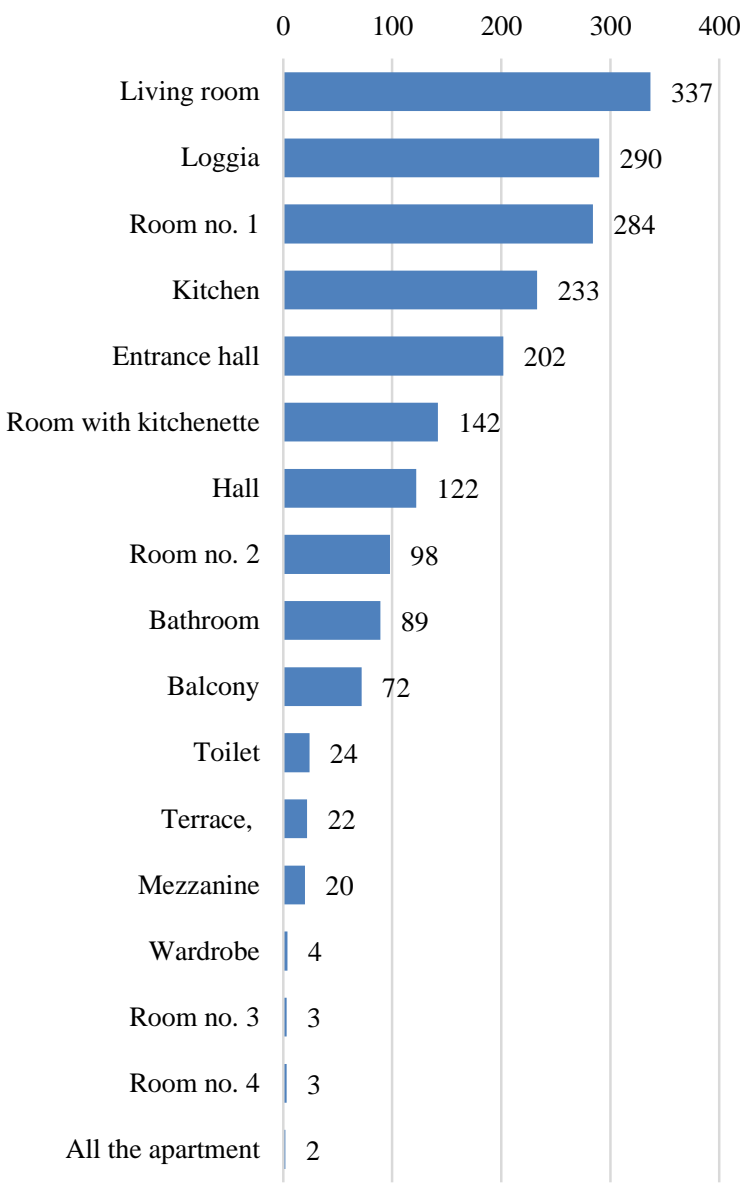

Fig. 1. Rooms where defects occur most frequently 
The most frequently occurring defects are cracks in walls and ceilings, scratched glass, lack of straight angles between walls or scratched window sills.

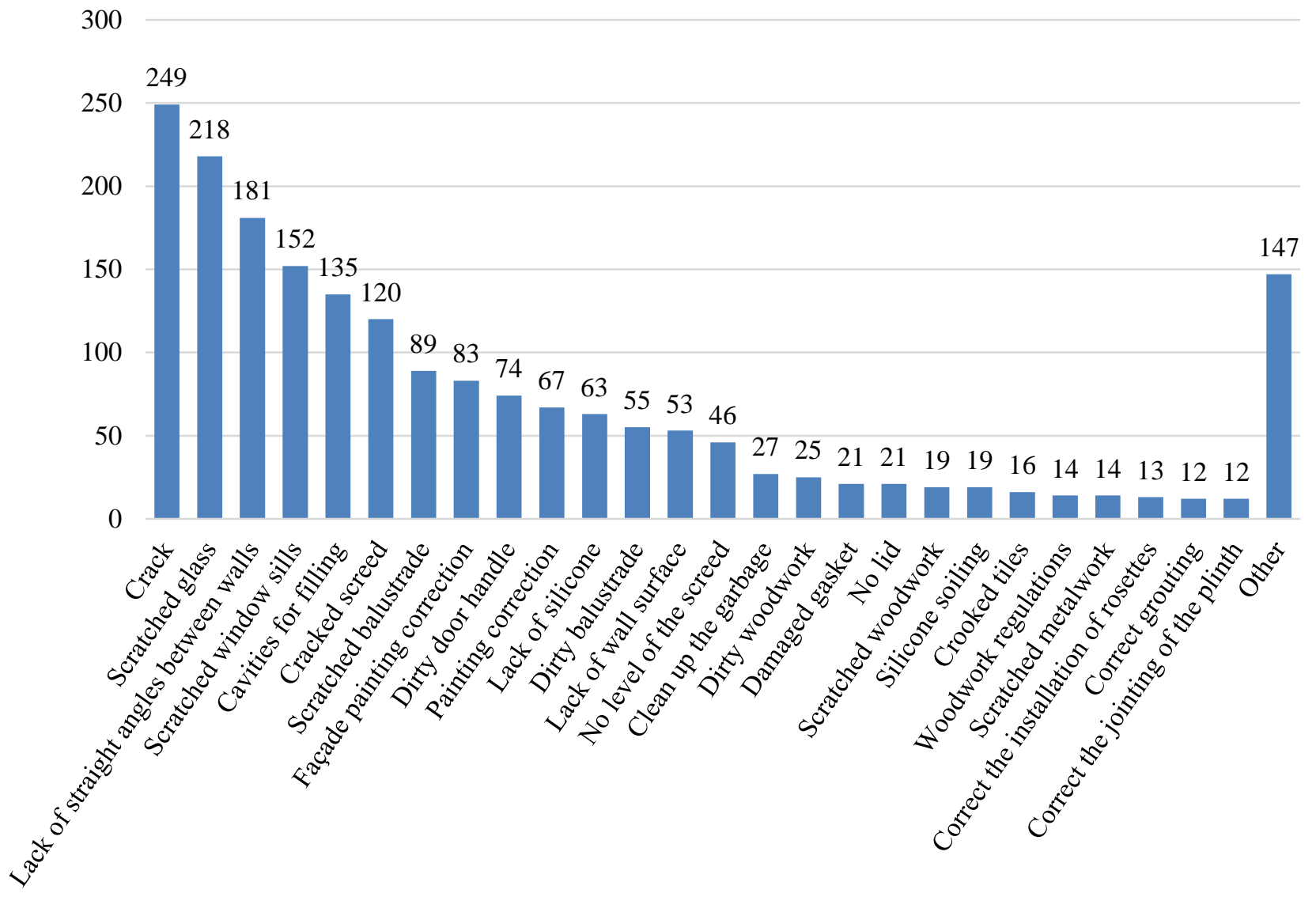

Fig. 2. The most frequent defects in buildings

The research also identified the elements of the building on which defects appear most frequently (Fig. 3).

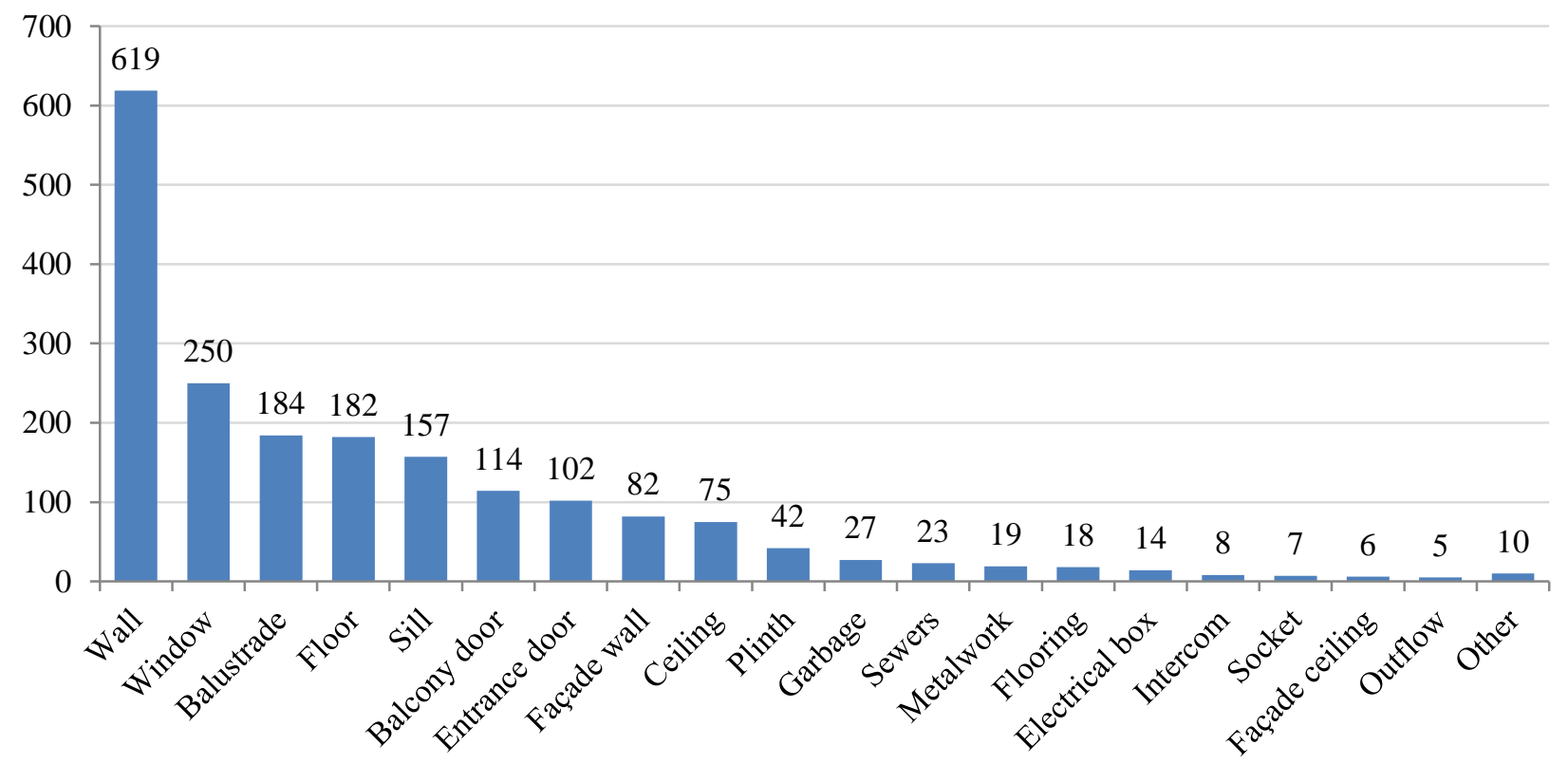

Fig. 3. Elements of the building on which defects occur most frequently 
The flats examined had different usable space as well as the number of rooms. Therefore, it was decided to check whether these parameters affect the overall number of defects. The results are presented in Figures 4 and 5 . Base on the graphs, the number of defects per $\mathrm{m} 2$ increases with decrease in size (square meters) and type (decrease in number of rooms) of an apartment. There was very small sample size for five-room apartment with size over $100 \mathrm{~m} 2$, therefore the results for this range may be disproportionate compared to the other groups.

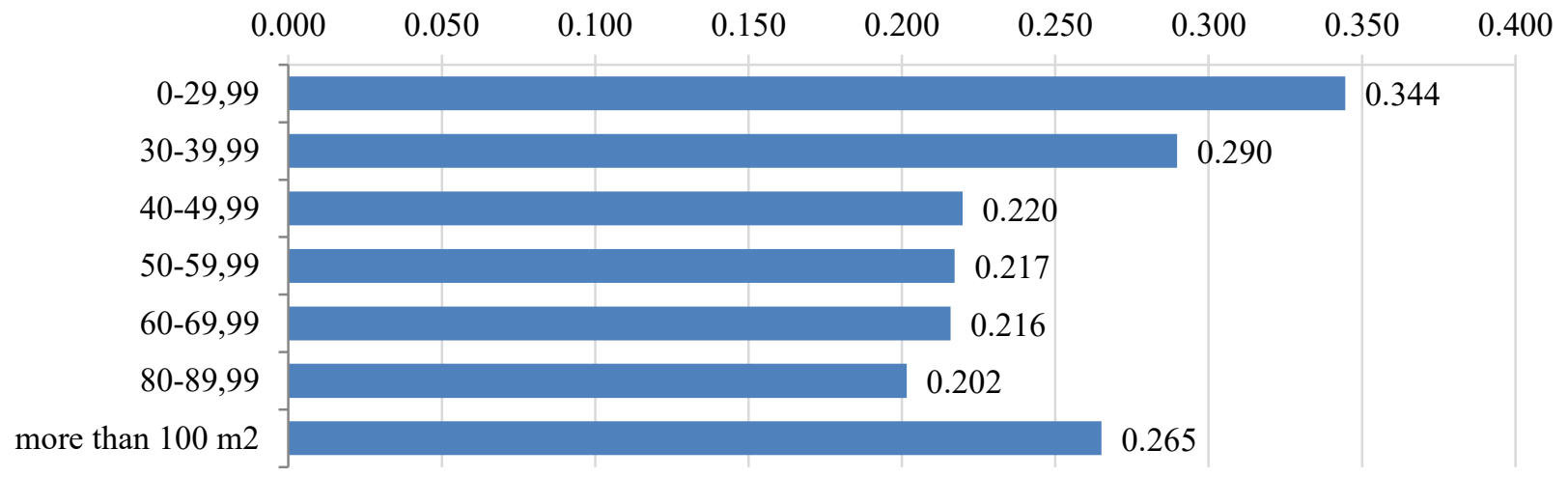

Fig. 4. Average number of defects per $\mathrm{m} 2$ of flat (division of flats by their area)

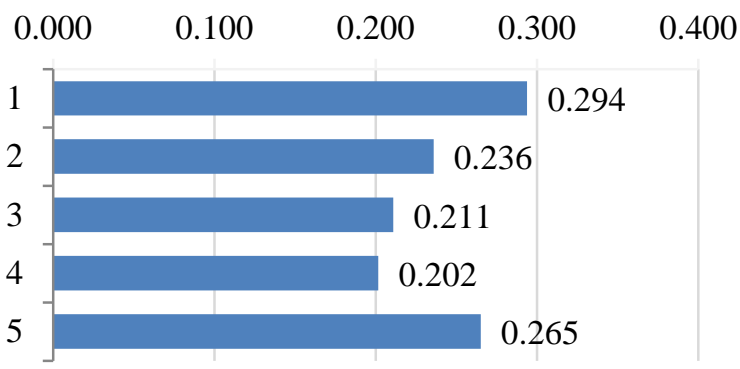

Fig. 5. Average number of defects per $\mathrm{m} 2$ of flat (division of flats by the number of rooms in the apartment)

For the purpose of developing a procedure and a subsequent mathematical model supporting acceptance decisions, the defects were divided into three basic groups on the grounds of their significance (Fig. 6).

Defects of little significance can be defined as those requiring a slight and non-intrusive interference in the object of acceptance. Such defects require cleaning, removing the material allowance or a slight chipping of the element, and the most common ones include: scratched window sill (152), scratched balustrade (89), dirty door handle (74) and painting correction (66).

Medium-sized defects require a greater amount of work and material to remove them, but they do not constitute a strong obstacle to handing over the flat. These include: scratched glass (218), cavities for filling in walls and ceilings (135), façade painting correction (83) and lack of silicone in flashing elements and plinths (63).

Very significant defects denote those that prevent the handover the keys to the flat owner, due to the need for the contractor to carry out complex works in terms of labor consumption and technology for their implementation or those that prevent the operation of the apartment, for example: plaster cracks (249), no straight angle between walls (181) and cracked screed (120).

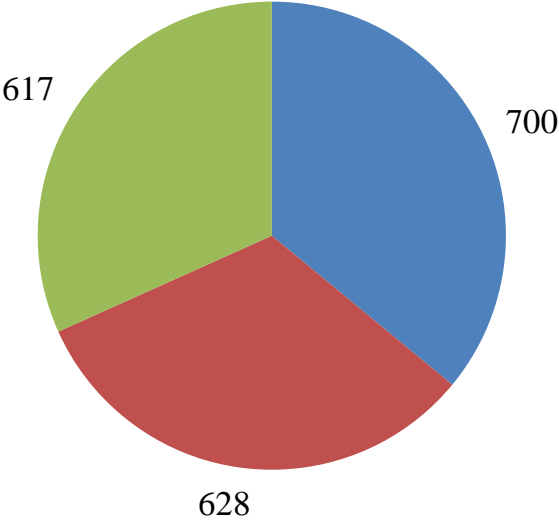

$\square$ Very significant $\square$ Significant $\square$ Insignificant

Fig. 6. Number of defects grouped according to their severity

In the building analysed, a total of 1945 defects were detected, where about $30 \%$ of them can be classified as very significant defects, thus requiring repair by the contractor. Two apartments were not accepted by the supervision inspector. On average, there were 11.32 defects per one flat and 0.23 defects per $\mathrm{m} 2$ of flat area.

\section{Flat acceptance procedure}

The contract between the developer and the buyer of the flat is regulated by the Act on protecting the rights of purchasers of apartments and houses [19]. Art. $27 \mathrm{sec} .1$ discusses the need to accept apartments: the article states that the handover of ownership of the premises to the buyer must be preceded by the acceptance of the apartment, which is preceded by the notice of completion of the construction, with no objection from the competent authority or based on the decision on the use permit. The acceptance is made in the presence of the buyer. A handover inspection report is made in which the owner can notify defects of the apartment. Within 14 days of 
signing the report, the development company is obliged to provide the buyer with a declaration of recognition or refusal to recognize the defects, along with the causes. The developer is obliged to remove the defects recognized in the apartment within 30 days of signing the apartment handover inspection report. If the developer, despite due diligence, does not remove the defect in the abovementioned period, an appropriate, different date for removal of the defects along with the justification for the delay may be indicated [19]. In the case of defects not settled in the property development act [19], the provisions of the Civil Code [3] shall apply. According to art. 22 para. 1 point 6 [19], the developer contract should contain the determination of the area and layout of the rooms, as well as the scope and standard of finishing works to be performed by the developer: the article mentioned regulates the developer's obligations towards the scope of finishing works as well as their standard.

Fig. 7 presents the procedure for the handover of apartments. The procedure has the following elements: - After obtaining a permit for the use of a residential building, the apartment is accepted by the supervision inspector.

- When inspecting the flat, the inspector indicates the defects; if none have been detected, the inspector issues a decision to hand over the flat to the owner.

- If the inspector's acceptance showed insignificant defects, the inspector issues a positive decision and hands over the flat to the owner. When very significant defects are found, the inspector issues a negative decision. In the case of significant defects, the inspector makes the decision about the handover on the basis of the inspection of the flat.

- After repairing the indicated defects, the inspector repeats the handover of the flat, and records it in the handover inspection report.

- Then the apartment acceptance is done by the owner. The owner indicates defects during the handover. If none has been found, the apartment is accepted.

- If the acceptance by the owner has shown insignificant defects, the apartment is handed over, except that the developer agrees to repair the defects indicated within the prescribed period. When very significant defects have been detected, the owner does not accept the apartment: the flat is directed to a new handover, repair of the defects, etc. In the case of significant defects, the owner decides whether to accept the apartment with the repair of the defects within the deadline specified in the handover inspection report, or not to accept the flat for the supervision inspector to hand it over again.

The procedure that has been developed is based on polish regulations [19] and is in full compliance with them. It should be noted that the legal regulations only set the general framework for flat acceptance so investors apply their own practices. Because of lack off full and detail procedure the authors took attempt to develop one. In the proposed procedure, the authors recommend to group the defects, as well as the related course of action. The procedure has been enriched with many years of experience of authors dealing with the acceptance of apartments in development investments as well as real estate development companies. Following the procedure and taking into account severity of housing defects during the handover process, may shorten time to receive a flat and drive a decrease in the cost of repairing defects, what will be analyzed in subsequent publications.

The authors' further scientific considerations will include the valuation of defects found in the building.

The research objective set should lead to the development of a decision-making tool used by the supervision inspector to decide on the acceptance of the flat due to the cost of repairing defects detected during the reception of the apartment by the inspector and the owner.

\section{Conclusions}

Each construction differs from all other buildings, which is the reason for the existence of various defects in the works of various industries in each building constructed (even by the same contractor). It is always necessary to systematically control the course of preparation and implementation of the development venture, that is, from the design assumptions, to the final acceptance of the buyer's flat.

The article presents the most frequent housing defects, so involved parties may pay particular attention to them and finally increase number of defects detected during handover process.

During the analysed handovers, it was found that the most frequently occurring defects include: cracks in walls and ceilings, scratched glass, lack of right angles between walls and scratched window sills. There was an average of 11.32 defects per apartment and 0.23 defects per square meter of apartments. In the building analysed, 1945 defects were found, while very significant, significant and insignificant defects had a similar quantitative share.

The investors apply their own procedures of flat acceptance, because the legal regulations only set the general framework for flat acceptance. There is a lack of full and detail procedure so the authors took attempt to develop one. Following the procedure may drive a decrease in the cost of repairing defects and shorten time to receive a flat, what will be analyzed in subsequent publications.

Further scientific considerations of the authors will concern the valuation of defects found in the building by both the inspector and the buyer of the apartment.

The authors are planning to create a decision-making tool that can be used to make a decision by the supervision inspector about the acceptance of the flat according to the cost of the repair of the defects found during the reception of the dwelling by the inspector and the owner. The tool will be based on the procedure for the acceptance of apartments presented in the paper. 


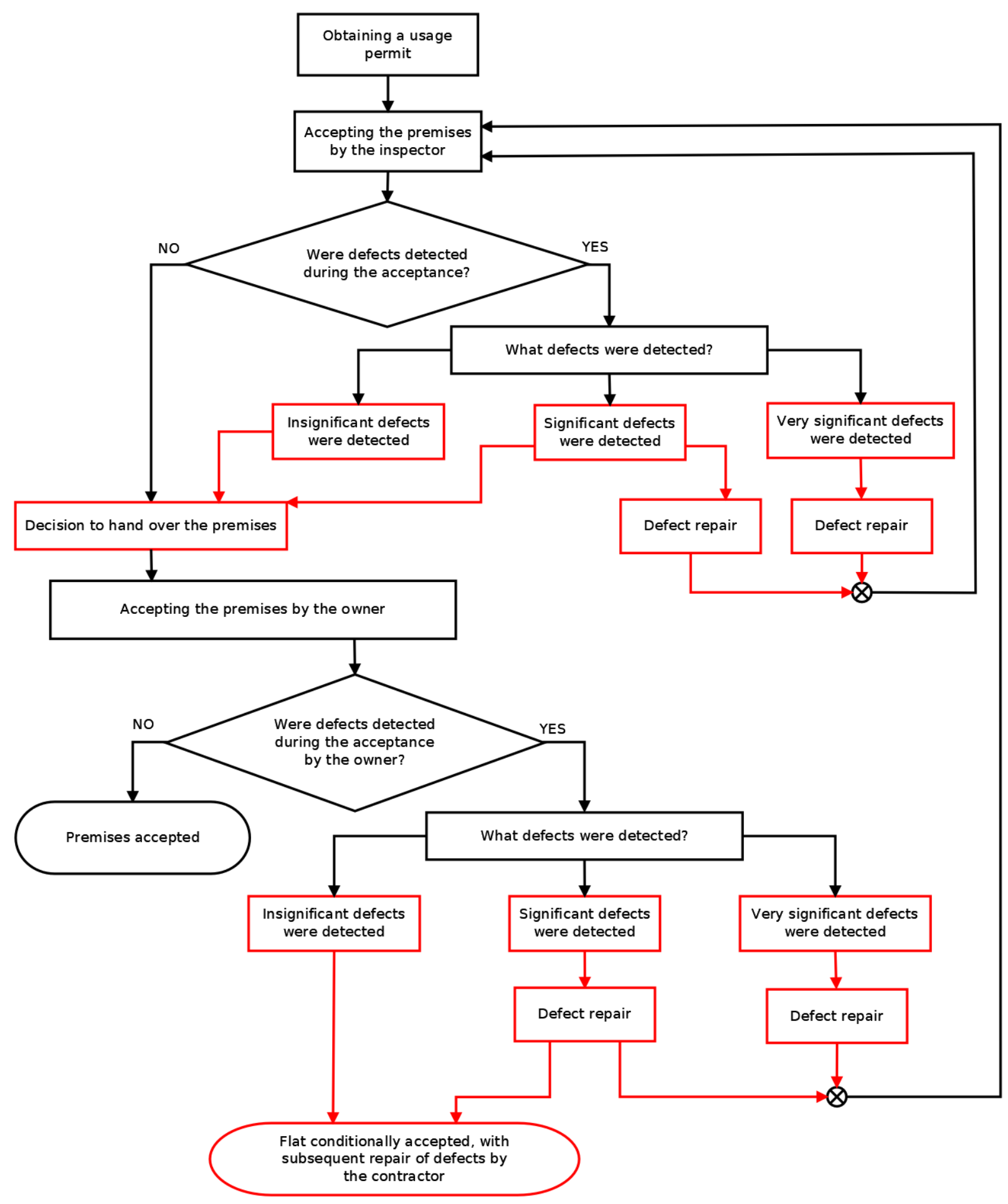

Fig. 7. Flat acceptance procedure 


\section{References}

1. E. Plebankiewicz, M. Juszczyk, J. Malara. Prz. Nauk., 65, 271-278 (2014)

2. G. Chrabczyński, A. Heine, Definicja wady budowlanej. Retrieved from : http://www.inzynierbudownictwa.pl/biznes,prawo,art ykul,definicja_wady_budowlanej,28 (2006)

3. Dz.U.2017.0.459 - Ustawa z dnia 23 kwietnia 1964 r. - Kodeks cywilny

4. N. Ahzahar, N. A. Karim, S. H. Hassan, J. Eman. Procedia Eng., 20, 249-255 (2011)

5. N. O. B. Nurul, O. M. Md Azree. EJTD, 3, 4-17 (2014)

6. I. Ismail, A. I. Che-Ani, M. Razak, N. Mohd Tawil, S. Johar. J Teknol, 75, 83-88 (2015)

7. F. E. Rotimi, J. Tookey, J. O. Rotimi. Buildings, 5, 3955 (2015)

8. F. E. Rotimi, An evaluative framework for defects in new residential buildings: the New Zealand case. (AUT, Auckland, 2013)

9. A. M. Ojo, O. O. Ijatuyi. IJCECEM, 2, 16-30 (2014)

10. D. B. Hammad, N. Shafiq, M. F. Nuruddin. MATEC web. conf., 15, 1-7 (2014)

11. J. M. M. Fernandez, C. P. González, V. Cabal, J. V. Balsera. Rev. Constr., 15, 106-114 (2016)

12. S. Dubas, P. Nowotarski, R. Milwicz. Mat. Bud., 6/2016, 166-167 (2016)

13. R. Oswald, R. Abel, Wady i usterki w budynkach. (Instalator Polski, Warszawa, 2000)

14. J. Czupajłło, Usterki $w$ pracach budowlanych $i$ wykończeniowych. (PWN, Warszawa, 2017)

15. K. Zima, Analiza deweloperskich przedsięwzięć budowlanych z zastosowaniem logiki rozmytej. Praca doktorska. (PK, Kraków, 2007)

16. M. Połoński, Proces inwestycyjny $i$ eksploatacja obiektów budowlanych. (Wyd. SGGW, Warszawa, 2008)

17. E. Plebankiewicz, A. Dziadosz. Prz. Bud., 5/2006, 4549 (2006)

18. R. Kozik, K. Zima. Prob. Rozw. Miast, 4/2013, 41-52 (2013)

19.Dz. U. 2011 nr 232 poz. 1377 - Ustawa z dnia 16 września 2011 r. o ochronie praw nabywcy lokalu mieszkalnego lub domu jednorodzinnego. 